\title{
AGROTEKNIKA
}

ISSN: 2685-3450 (Online)

www.agroteknika.id

ISSN: 2685-3450 (Print)

\section{Analisis Variasi Konsentrasi Asam Sulfat sebagai Aktivasi Arang Aktif Berbahan Batang Tembakau (Nicotiana Tabacum)}

\section{Variation Analysis of Sulfuric Acid Concentration as Activation of Active Charcoal Made from Tobacco Stems (Nicotiana tabacum)}

\author{
Mohammad Amirudin, Elida Novita*, Tasliman
}

\author{
Program Studi Teknik Pertanian, Fakultas Teknologi Pertanian, Universitas Jember, \\ Indonesia \\ *Penulis Korespondesi \\ Email: elida_novita.ftp@unej.ac.id
}

\begin{abstract}
Abstrak. Pemanfaatan tembakau selama ini terfokus pada daun tembakau. Bagian lain dari tembakau seperti batang tembakau belum banyak dimanfaatkan. Batang tembakau memiliki kandungan selulosa, lignin, hemiselulosa, dan total organik karbon relatif tinggi yang berpotensi dimanfaatkan sebagai arang aktif. Aktivasi secara kimia menggunakan asam sulfat karena memiliki dampak positif terhadap daya jerap arang aktif. Riset ini bertujuan mengkaji pengaruh pemberian konsentrasi asam sulfat terhadap pembuatan arang aktif berbahan batang tembakau. Riset ini menggunakan metode eksperimen dengan membandingkan penambahan konsentrasi H2SO4 6\%, 8\%, 10\% pada pembuatan arang aktif batang daun tembakau dengan pengulangan sebanyak 3 kali pada setiap perlakuan. Analisis data dengan metode analysis of variance (ANOVA) dan uji lanjut Tukey pada taraf $\alpha \leq 0,05$. Hasil riset memperlihatkan bahwa konsentrasi H2SO4 pada pembuatan arang aktif batang tembakau berpengaruh pada variabel kandungan air, kandungan abu, kandungan zat terbang, kandungan karbon murni, serta energi serap iodium. Perlakuan terbaik dalam pembuatan arang aktif dari batang daun tembakau adalah dengan penambahan konsentrasi H2SO4 10\%. Nilai kandungan air, kadar abu, kadar zat terbang, kandungan karbon terikat, dan daya serap iodium secara berurutan yaitu 0, 040\%; 0, 035\%; 0, 877\%; 99, 088\%; dan 99,405 miligram/gram.
\end{abstract}

Kata kunci: tembakau, aktivasi, asam sulfat, arang aktif

Abstract. Tobacco use has been focused on the leaf. Other parts of tobacco such as the tobacco stem have not been widely used. Tobacco use has so far focused on tobacco leaves. Other parts of tobacco such as tobacco stems have not been widely used. Tobacco stems are often still regarded as agricultural waste and have not been effectively treated. Tobacco stems contain cellulose, lignin, hemicellulose, and relatively high total organic carbon which has the potential to be used as activated charcoal. The chemical activation using sulfuric acid because sulfuric acid is very corrosive and the hydration reaction with water is very exothermic ie a reaction that releases heat. The research aims to describe the effect of added H2SO4 concentration on the manufacture of activated charcoal made from tobacco stems. This research used an experimental method with the treatment of 6\%, 8\%, 10\% H2SO4 concentration differences with three repetitions. Data analysis used analysis of variance (ANOVA) method and Tukey continued to test at $\alpha \leq 0.05$ level. The results reflected that the $\mathrm{H} 2 \mathrm{SO} 4$ concentration treatment to the production of activated charcoal of tobacco stems was 
very influential with variables such as water content, ash content, levels of flying substances, pure carbon content, and iodine absorption because it had significant values. The best treatment in the carbon activated was added concentration of 10\% $\mathrm{H} 2 \mathrm{SO} 4$ with a moisture content value of $0.040 \%$, ash content values $0.035 \%$, fly matter content value $0.877 \%$, bound carbon content value of $99.088 \%$, iodine absorption value is $994.05 \mathrm{mg} / \mathrm{g}$.

Keywords: tobacco, activation, sulfurid acid, activated charcoal

\section{Pendahuluan}

Tembakau merupakan salah satu komoditi unggulan di Kabupaten Jember. Pangsa pasar tembakau dari Kabupaten Jember adalah beberapa negara di Eropa (Muktianto \& Diartho, 2018). Pengolahan tanaman tembakau akan menghasilkan batang tembakau yang dinilai sebagai limbah. Potensi batang tembakau di Kabupaten Jember sebesar 267,840 ton (Badan Pusat Statistik Provinsi Jawa Timur, 2018). Menurut Himawanto and Nadjib (2013) menyatakan bahwa tanaman tembakau umumnya digunakan hanya bagian daun saja sedangkan bagian batang tembakau dianggap sebagai limbah pertanian kemudian dibakar. Bahan pertanian seperti batang tanaman tembakau mengandung karbon yang relatif tinggi. Selajan dengan pernyataan tersebut Sandi and Astuti (2014), menyebutkan bahwa bahan karbon berpori yang berasal dari bahan limbah padat pertanian bermanfaatan sebagai bahan baku pada pembuatan karbon aktif. Batang tembakau mengandung jumlah kandungan selulosa 56,10\%, lignin 15,11\%, hemiselulosa 22,44\%, total karbon organik 44,61\% (Kartikawati, 2016). Kandungan dalam batang tembakau dan besarnya potensi pemanfaatan limbah batang tembakau sebagai arang aktif dapat menjadi satu solusi untuk menghasilkan produk bernilai tambah tinggi dan mengurangi limbah pada lingkungan.

Arang aktif ataupun karbon aktif ialah media yang bisa menjerap senyawa kimia pada gas dan larutan berlandaskan prinsip pertukaran anion serta kation (Lempang, 2014). Contoh bahan baku arang aktif ialah batubara, kayu, dan limbah pertanian semacam batang tembakau. Tahapan pembuatan arang aktif terdiri atas karbonisasi serta aktivasi baik secara raga ataupun kimia. Karbonisasi ialah tahapan transformasi kimia bahan baku berdasarkan pirolisis dengan temperatur $500^{\circ} \mathrm{C}-800^{\circ} \mathrm{C}$ (Jankowska et al., 1991). Tahapan berikutnya ialah aktivasi arang aktif yang berperan untuk menambah luasan pori- pori sehingga energi jerapnya dapat maksimal. Terdapat bermacam bahan aktivator dalam pembuatan arang aktif. Menurut Setiawati and Suroto (2010), aktivasi secara kimia umumnya memakai logam alkali hidroksida, senyawa karbonat, sulfida, $\mathrm{ZnCl}_{2}$, asam sulfat, asam fosfat, serta natrium klorida yang ialah penyerap air( dehydrating agent). Asam sulfat merupakan bahan kimia anorganik yang bertabiat asam kokoh serta gampang larut dalam air. Asam sulfat banyak digunakan selaku agen pencampur di dalam industri, baik dalam industri gipsum, bensin, farmasi, 
pupuk, ataupun bleaching (Perry, 2008). Reaksi hidrasi atau pengenceran asam sulfat menggunakan air bersifat eksotermis atau suatu reaksi yang melepaskan kalor (Ukanwa et al., 2019).

Selama ini peningkatan nilai guna limbah batang daun tembakau yang telah dilakukan berupa produksi pulp (Indiarji, 2010) dan briket arang (Sumarta \& Sutapa, 2015). Hasil penelitian Novita et al. (2020), menyebutkan bahwa kandungan karbon atau C organik pada relatif lebih tinggi dibandingkan sekam padi dan kulit buah kopi. Kandungan bahan organik berupa $\mathrm{C}$ organik mendukung pemanfaatan batang daun tembakau sebagai arang aktif. Selain itu, aktivasi arang aktif menggunakan asam sulfat memberikan dampak positif terhadap kemampuan daya jerapnya sebagai absorben (Setiawati \& Suroto, 2010). Riset ini bertujuan mengkaji pengaruh pemberian konsentrasi asam sulfat terhadap pembuatan arang aktif berbahan batang tembakau.

\section{Bahan dan Metode}

\section{Alat dan Bahan}

Alat yang dipakai pada penelitian ini terdiri atas neraca analitik, oven, tanur, parang, loyang, penumbuk, ayakan 40 mesh, heater, kertas saring merk whatman nomor 42, cawan keramik atau porselen, labu ukur $500 \mathrm{~mL}$, beker gelas $1000 \mathrm{~mL}$, pipet tetes, erlemenyer 500 $\mathrm{mL}$, stirer, alumunium foil, dan desikator. Bahan penelitian terdiri atas ini adalah batang tembakau, $\mathrm{H}_{2} \mathrm{SO}_{4}$, iodium $\left(\mathrm{I}_{2}\right)$, indikator amilum, natrium thiosulfat $\left(\mathrm{Na}_{2} \mathrm{~S}_{2} \mathrm{O}_{3} .5 \mathrm{H}_{2} \mathrm{O}\right)$ dan aquades.

\section{Rancangan Penelitian}

Penelitian ini menggunakan perlakuan perbedaan konsentrasi $\mathrm{H}_{2} \mathrm{SO}_{4} 6 \%, 8 \%, 10 \%$ dengan pengulangan sebanyak tiga kali. Berdasarkan hasil kajian Asrijal et al. (2014) dan Setiawati and Suroto (2010), menunjukkan bahwa perbedaan konsentrasi $\mathrm{H}_{2} \mathrm{SO}_{4}$ berdampak cukup signifikan pada performa karbon aktif dari tempurung kelapa. Variabel yang diamati terdiri atas kandungan air, kandungan abu, kandungan zat terbang, kandungan karbon karbon terikat, dan daya serap larutan iodium. Rancangan percobaan dapat dilihat di Tabel 1. Pengambilan keputusan pada penelitian didukung berdasarkan analisis data. Analisis data menggunakan metode analysis of variance (ANOVA) dan uji lanjut Tukey pada taraf $\alpha \leq 0,05$.

\section{Proses Pembuatan Arang Aktif}

Pembuatan arang aktif berbahan dasar batang tembakau diawali dengan memilih batang tembakau kering. Kemudian sebanyak 500 gram batang tembakau tersebut dipotong berukuran sekitar 1-2,5 cm untuk mengecilkan ukuran. Batang tembakau dikarbonasi 
menggunakan tanur pada suhu $400^{\circ} \mathrm{C}$ selama 60 menit untuk menguraikan selulosa organik menjadi unsur karbon. Arang hasil karbonasi kemudian didinginkan di dalam alat penyerap uap air. Setelah suhunya sesuai dengan suhu ruang, karbon selanjutnya dikumpulkan, ditimbang dan disimpan (Asrijal et al., 2014). Arang batang tembakau yang dihasilkan dari proses karbonasi kemudian ditumbuk, diayak dengan ayakan 40 mesh, butiran arang aktif batang tembakau kemudian diaktifkan secara kimia yaitu direndam dengan menggunakan $\mathrm{H}_{2} \mathrm{SO}_{4}$ konsentrasi $(6 \%, 8 \%, 10 \%)$ masing-masing sebanyak $500 \mathrm{ml}$ selama 24 jam. Kemudian arang dicuci dengan aquades. Kemudian karbon yang sudah siap diletakkan dalam alat pembakaran atau tanur pada temperatur $500^{\circ} \mathrm{C}$ dengan waktu pemanasan selama 60 menit untuk mengaktifkan karbon di dalamnya. Karbon aktif dimasukkan ke alat penyerap uap air atau desikator dan siap untuk diuji mutunya (Asrijal et al., 2014).

Tabel 1. Rancangan percobaan pengukuran variabel uji

\begin{tabular}{lccc}
\hline \multirow{2}{*}{ Variasi Konsentrasi (\%) } & \multicolumn{3}{c}{ Ulangan } \\
\cline { 2 - 4 } & I & II & III \\
\hline T6 $=$ Kadar 6\% & T61 & T62 & T63 \\
T8 $=$ Kadar 8\% & T81 & T82 & T83 \\
T10 = Kadar 10\% & T101 & T102 & T103 \\
\hline
\end{tabular}

\section{Hasil dan Pembahasan}

\section{Karakteristik Arang Aktif Batang Tembakau}

Kadar air

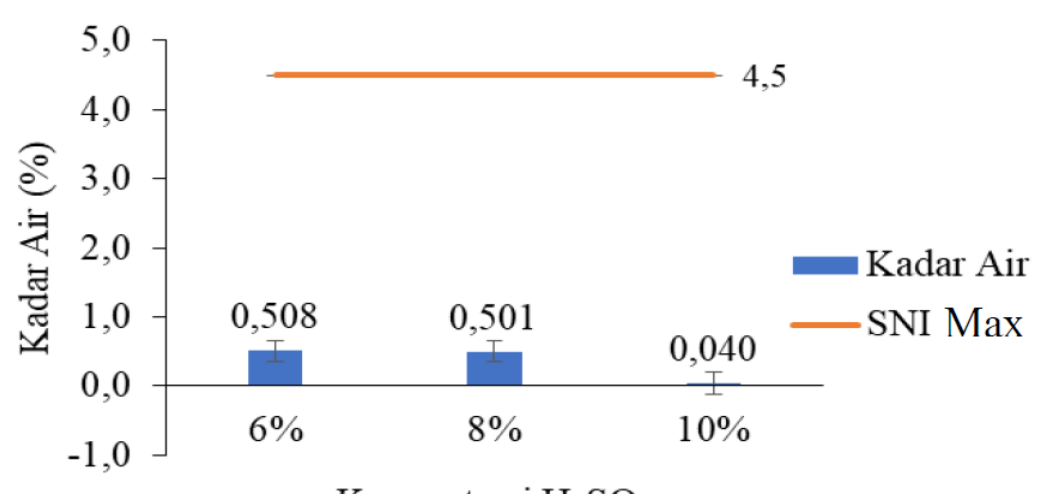

Konsentrasi $\mathrm{H}_{2} \mathrm{SO}_{4}$

Gambar 1. Grafik nilai kadar air arang aktif batang tembakau

Berdasarkan Gambar 1, nilai kadar air tertinggi secara berturut-turut dihasilkan arang aktif dengan konsentrasi $\mathrm{H}_{2} \mathrm{SO}_{4} 6 \%$ yaitu sebesar $0,508 \%$, konsentrasi $\mathrm{H}_{2} \mathrm{SO}_{4} 8 \%$ sebesar 0,501\%, konsentrasi $\mathrm{H}_{2} \mathrm{SO}_{4} 10 \%$ sebesar 0,040\%. Merujuk pada Standar Nasional Indonesia No. 06-3730-1995, syarat kandungan air pada arang aktif dalam bentuk butiran maksimum adalah 4,5\% (Badan Standarisasi Nasional (BSN), 1995). Hal - hal lain yang mempengaruhi 
kandungan air pada arang aktif yaitu sifat bahan arang aktif yang mudah menyerap uap air dan molekul uap air yang tertahan di dalam kisi-kisi heksagonal karbon aktif terutama pada penurunan suhu karbon aktif (Budiono et al., 2009).

\section{Kadar abu}

Gambar 2 menunjukkan bahwa hasil pengukuran kadar abu arang aktif berbahan batang tembakau berkisar antara $0,035 \%$ hingga $0,083 \%$. Nilai rata-rata kandungan abu pali rendah ada di sampel arang dari batang daun tembakau dengan konsentrasi asam sulfat $8 \%$ dan $10 \%$ yaitu sebesar $0,035 \%$ dan 0,035\%. Kadar abu terbanyak ada di sampel karbon dengan konsentrasi $\mathrm{H}_{2} \mathrm{SO}_{4} 6 \%$ yaitu sebesar $0,083 \%$. Nilai kadar abu pada arang aktif berbahan batang tembakau tiap masing-masing konsentrasi memenuhi standar kualitas arang aktif pada Standar Nasional Indonesia yang menetapkan nilai kandungan abu dari karbon aktif dalam bentuk butiran maksimum sebesar 2,5\% (Badan Standarisasi Nasional (BSN), 1995). Kandungan abu ini menggambarkan kemurnian dari arang aktif yang diproduksi. Hal tersebut mengindikasikan bahwa jika semakin murni arang aktif yang diproduksi maka semakin bagus mutu arang aktif yang diproduksi (Malik, 2013). Tingginya kadar abu yang diperoleh dapat berdampak pada daya serap. Pori karbon aktif akan dipenuhi oleh unsur-unsur logam yang menjadi bagian penyusun utama dalam abu seperti kalium, natrium, kalsium, dan magnesium (Malik, 2013).

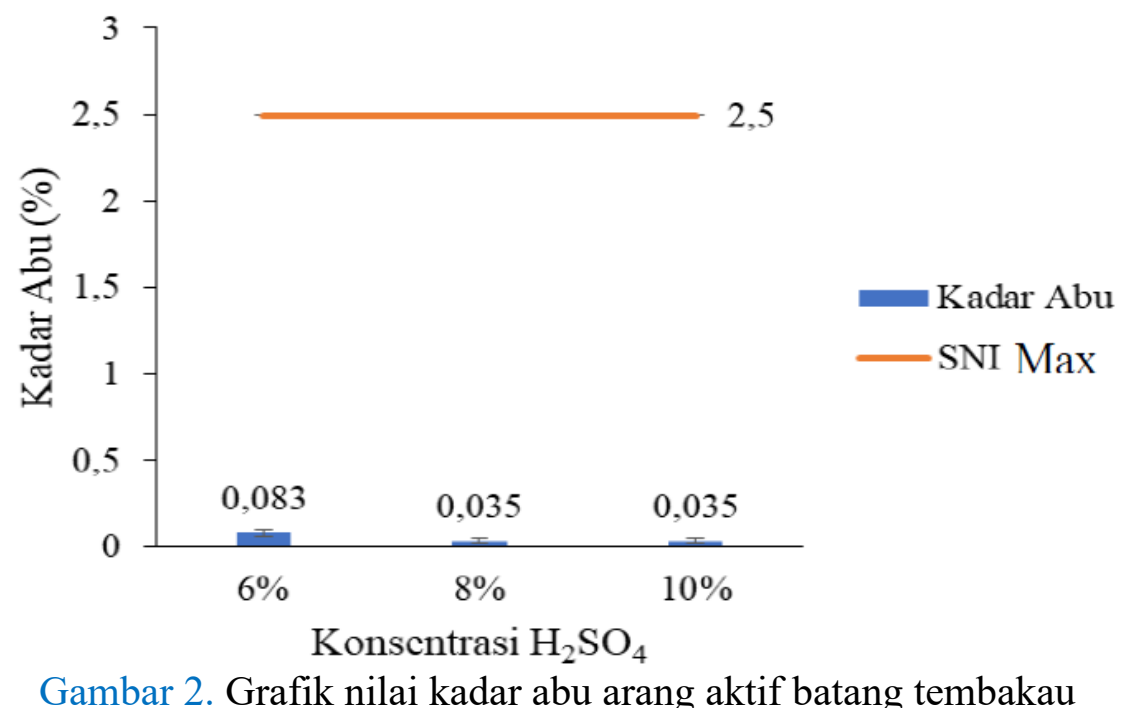

\section{Kadar zat terbang}

Berdasarkan Gambar 3, kandungan zat terbang tertinggi secara berturut-turut dihasilkan arang aktif dengan konsentrasi $\mathrm{H}_{2} \mathrm{SO}_{4} 6 \%$ yaitu sebesar $0,962 \%$, konsentrasi $\mathrm{H}_{2} \mathrm{SO}_{4} 8 \%$ sebesar 0,943\%, konsentrasi $\mathrm{H}_{2} \mathrm{SO}_{4} 10 \%$ sebesar 0,877\%. Merujuk pada Standar Nasional Indonesia menyebutkan bahwa ketentuan standar kadar zat terbang dari arang aktif dalam 
bentuk butiran maksimum adalah 15\% (Badan Standarisasi Nasional (BSN), 1995). Dari Gambar 3 terlihat bahwa kadar zat terbang dengan bahan aktivator $\mathrm{H}_{2} \mathrm{SO}_{4}$ memenuhi persyaratan. Fluktuasi nilai kandungan zat terbang yang diperoleh menggambarkan bahwa bagian luar atau permukaan karbon aktif masih diselimuti oleh zat non karbon yang tertahan pada lapisan terluarnya dalam bentuk $\mathrm{C}\left(\mathrm{H}_{2}\right)$, zat tersebut merupakan suatu senyawa penghambat yang mampu menyeliputi rongga atau pori-pori pada dari karbon aktif, oleh sebab itu mempengaruhi kemampuan daya serapnya (Lempang, 2014).

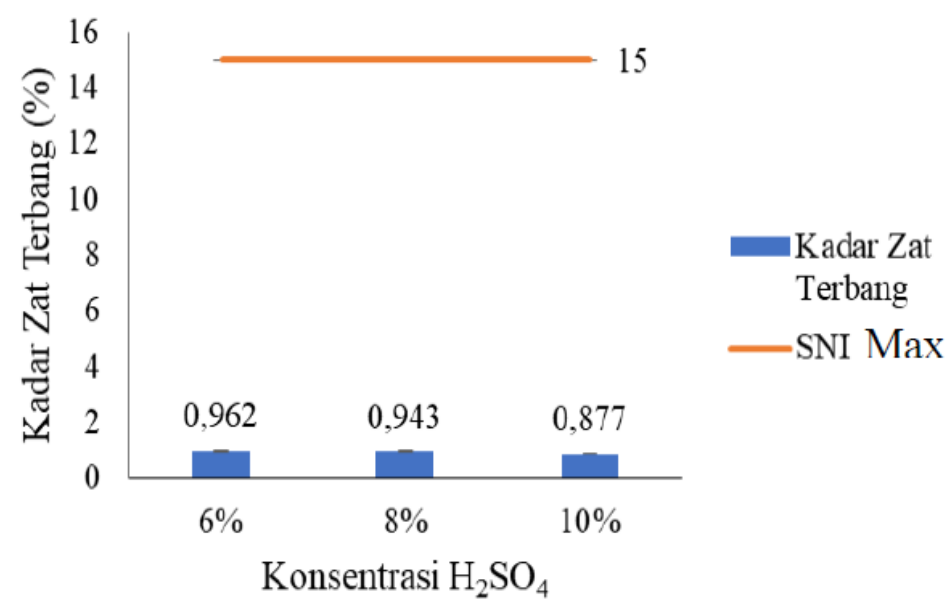

Gambar 3. Grafik nilai kadar zat terbang arang aktif batang tembakau

\section{Kandungan karbon terikat}

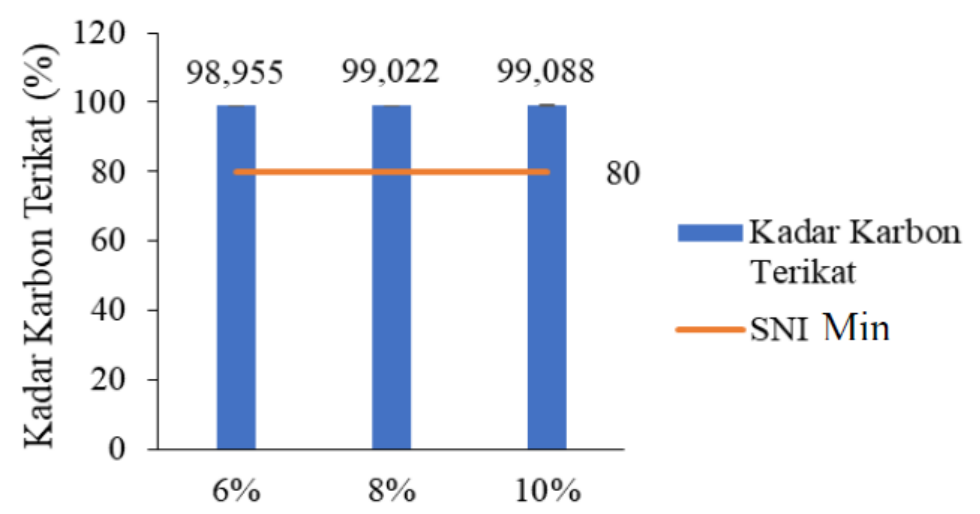

Konsentrasi $\mathrm{H}_{2} \mathrm{SO}_{4}$

Gambar 4. Grafik nilai kadar karbon terikat arang aktif batang tembakau

Berdasarkan Gambar 4, kandungan karbon terikat tertinggi secara berturut-turut dihasilkan arang aktif dengan konsentrasi $\mathrm{H}_{2} \mathrm{SO}_{4}$ 10\% yaitu sebesar 99,08\%, konsentrasi $\mathrm{H}_{2} \mathrm{SO}_{4} 8 \%$ sebesar 99,02\%, konsentrasi $\mathrm{H}_{2} \mathrm{SO}_{4} 6 \%$ sebesar 98,95\%. Berdasarkan Standar Nasional Indonesia standar kadar zat terbang dari karbon aktif dalam bentuk butiran minimum sebesar 80 \% (Badan Standarisasi Nasional (BSN), 1995). Dari Gambar 4 terlihat bahwa kadar karbon murni dengan bahan aktivator $\mathrm{H}_{2} \mathrm{SO}_{4}$ memenuhi persyaratan. Menurut Malik (2013) menyatakan besar kecilnya kandungan karbon terikat yang diperoleh selain 
dipengaruhi oleh kandungan abu dan zat terbang, juga disebabkan oleh kadar selulosa dan lignin yang dapat diubah dalam bentuk atom karbon.

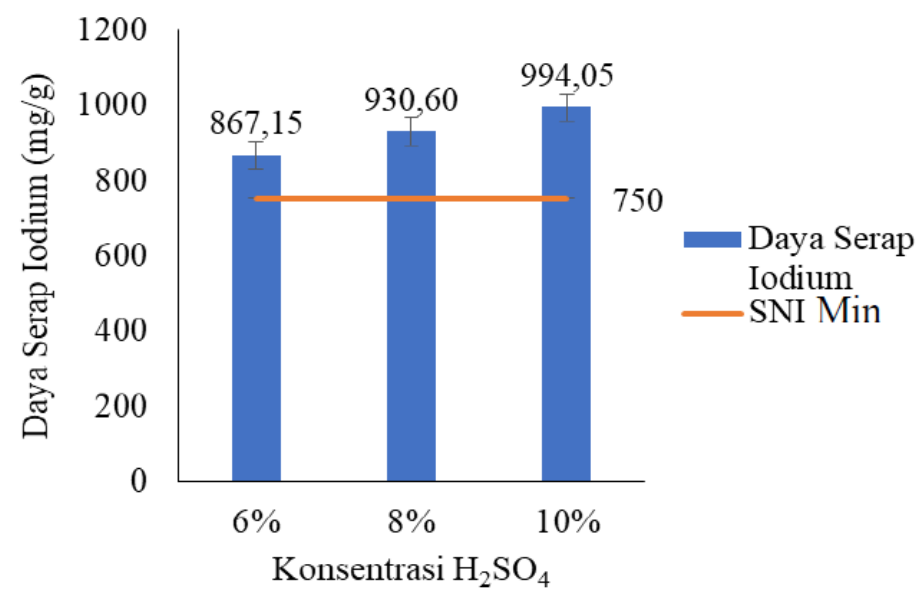

Gambar 5. Grafik nilai kadar daya serap arang aktif batang tembakau

\section{Kadar daya serap larutan iodium}

Berdasarkan Gambar 5, nilai kadar daya serap larutan iodium tertinggi secara berturutturut dihasilkan arang aktif dengan konsentrasi $\mathrm{H}_{2} \mathrm{SO}_{4} \quad 10 \%$ yaitu sebesar 994,05 mg/g, konsentrasi $\mathrm{H}_{2} \mathrm{SO}_{4} 8 \%$ sebesar 930,6 mg/g, konsentrasi $\mathrm{H}_{2} \mathrm{SO}_{4} 6 \%$ sebesar 867,15 mg/g. Merujuk pada Standar Nasional Indonesia, standar daya serap larutan iodium dari arang aktif dalam bentuk butiran minimum adalah 750 miligram/gram (Badan Standarisasi Nasional (BSN), 1995). Aktivasi memberikan pengaruh signifikan dalam pengembangan struktur pori sehingga daya serap terhadap iodin meningkat (Setiawati \& Suroto, 2010).

Tabel 2. Perhitungan ANOVA satu arah karakteristik arang aktif batang tembakau

\begin{tabular}{clrrrrl}
\hline & & $\begin{array}{c}\text { Sum of } \\
\text { Squares }\end{array}$ & $d f$ & $\begin{array}{c}\text { Mean } \\
\text { Square }\end{array}$ & $F$ & \multirow{2}{*}{ Sig. } \\
\hline \multirow{2}{*}{ Kandungan } & Between groups & 0,433 & 2 & 0,217 & 380,891 & 0,000 \\
air & Within groups & 0,003 & 6 & 0,001 & & \\
& Total & 0,437 & 8 & & & \\
\hline \multirow{2}{*}{ Kadar abu } & Between groups & 0,005 & 2 & 0,002 & 60,878 & 0,000 \\
& Within groups & 0,000 & 6 & 0,000 & & \\
& Total & 0,005 & 8 & & & \\
\hline \multirow{2}{*}{ Kadar zat } & Between groups & 0,012 & 2 & 0,006 & 109,195 & 0,000 \\
terbang & Within groups & 0,000 & 6 & 0,000 & & \\
& Total & 0,012 & 8 & & & 0,000 \\
Kadar & Between groups & 0,026 & 2 & 0,013 & 177,060 & 0,000 \\
karbon & Within groups & 0,000 & 6 & 0,000 & & \\
murni & Total & 0,027 & 8 & & & \\
\hline Daya serap & Between groups & 24155,415 & 2 & 12077,708 & 9,000 & 0,016 \\
\hline \multirow{2}{*}{ Iodium } & Within groups & 8051,805 & 6 & 1341,968 & & \\
& Total & 32207,220 & 8 & & & \\
\hline
\end{tabular}




\section{Pengaruh Penambahan Konsentrasi $\mathrm{H}_{2} \mathrm{SO}_{4}$ terhadap Pembuatan Arang Aktif}

Hasil perhitungan uji ANOVA dari pembuatan arang aktif batang tembakau disajikan dalam Tabel 2.

Merujuk pada analisis dengan ANOVA pada Tabel 2, diketahui bahwa penambahan konsentrasi $\mathrm{H}_{2} \mathrm{SO}_{4}$ pada beberapa variabel seperti kandungan air, kandungan abu, kandungan zat terbang, kandungan karbon murni, dan daya serap iodium karena nilai signifikan pada taraf sig $<0,05$ sehingga perlu uji lanjut untuk menentukan tingkat perbedaan melalui uji lanjut Tukey. Abjad yang mirip dalam satu kolom merepresentasikan pelakuan yang tidak berbeda secara signifikan pada taraf $\alpha 0,05$.

Hasil uji lanjut Tukey (Tabel 3) dapat dilihat bahwa pada variabel kadar air, kadar abu, kadar zat terbang, kadar karbon murni, dan daya serap iodium mempunyai nilai yang berbeda secara nyata di tiap perlakuannya. Perbedaan tersebut disebabkan oleh terdapatnya abjad yang berbeda pada tiap perlakuan. Pada variabel kadar air dengan perlakuan $\mathrm{H}_{2} \mathrm{SO}_{4} 6 \%$ tidak berbeda nyata $\mathrm{H}_{2} \mathrm{SO}_{4} 8 \%$ dan mempunyai nilai yang berbeda nyata dengan perlakuan $\mathrm{H}_{2} \mathrm{SO}_{4}$ $10 \%$. Pada variabel kadar abu dengan perlakuan $\mathrm{H}_{2} \mathrm{SO}_{4} 6 \%$ berbeda nyata dengan perlakuan $\mathrm{H}_{2} \mathrm{SO}_{4} 8 \%$ dan tidak berbeda nyata $\mathrm{H}_{2} \mathrm{SO}_{4} \quad 10 \%$. Pada variabel kadar zat terbang dengan perlakuan $\mathrm{H}_{2} \mathrm{SO}_{4} 6 \%$ berbeda nyata dengan perlakuan $\mathrm{H}_{2} \mathrm{SO}_{4} \quad 8 \%$ dan $\mathrm{H}_{2} \mathrm{SO}_{4} \quad 10 \%$. Pada variabel kadar karbon murni dengan perlakuan $\mathrm{H}_{2} \mathrm{SO}_{4} 6 \%$ berbeda nyata dengan perlakuan $\mathrm{H}_{2} \mathrm{SO}_{4} 8 \%$ dan $\mathrm{H}_{2} \mathrm{SO}_{4} 10 \%$. Pada variabel daya serap iodium dengan perlakuan $\mathrm{H}_{2} \mathrm{SO}_{4} 8 \%$ tidak berbeda nyata dengan perlakuan $\mathrm{H}_{2} \mathrm{SO}_{4} \quad 6 \%$ dan perlakuan $\mathrm{H}_{2} \mathrm{SO}_{4} \quad 10 \%$ karena mempunyai dua abjad serta perlakuan $\mathrm{H}_{2} \mathrm{SO}_{4} 6 \%$ mempunyai nilai berbeda nyata dengan perlakuan $\mathrm{H}_{2} \mathrm{SO}_{4} 10 \%$ karena memiliki abjad yang berbeda. Berdasarkan hasil uji statistik menggunakan ANOVA dan uji lanjut Tukey diperoleh kesimpulan bahwa penambahan konsentrasi $\mathrm{H} 2 \mathrm{SO} 4$ 10\% menjadi perlakuan terbaik. Hal tersebut juga diduukung oleh variabel kadar air, kadar abu, dan daya serap iodium yang lebih baik daripada perlakukan penambahan $\mathrm{H}_{2} \mathrm{SO}_{4} 6 \%$ dan $8 \%$.

Tabel 3. Hasil Uji Tukey karakteristik arang aktif batang tembakau

\begin{tabular}{llll}
\hline \multicolumn{1}{c}{ Variabel } & \multicolumn{1}{c}{$\mathrm{H}_{2} \mathrm{SO}_{4} 6 \%$} & \multicolumn{1}{c}{$\mathrm{H}_{2} \mathrm{SO}_{4} 8 \%$} & $\mathrm{H}_{2} \mathrm{SO}_{4} 10 \%$ \\
\hline Kadar air & $0,5083 \pm \mathrm{b}$ & $0,5013 \pm \mathrm{b}$ & $0,0393 \pm \mathrm{a}$ \\
Kadar abu & $0,0830 \pm \mathrm{b}$ & $0,0347 \pm \mathrm{a}$ & $0,0350 \pm \mathrm{a}$ \\
Kadar zat terbang & $0,9617 \pm \mathrm{c}$ & $0,9427 \pm \mathrm{b}$ & $0,8770 \pm \mathrm{a}$ \\
Kadar karbon murni & $98,9553 \pm \mathrm{a}$ & $99,0223 \pm \mathrm{b}$ & $99,0880 \pm \mathrm{c}$ \\
Daya serap iodium & $867,1500 \pm \mathrm{a}$ & $930,6000 \pm \mathrm{ab}$ & $994,0500 \pm \mathrm{b}$ \\
\hline
\end{tabular}

Keterangan: Abjad yang mirip atau serupa dalam satu deret kolom menunjukan nilai yang tidak berbeda signifikan secara statistik pada taraf $\alpha \leq 0,05$ uji Tukey. 


\section{Kesimpulan}

Hasil penelitian menunjukkan bahwa penambahan konsentrasi $\mathrm{H}_{2} \mathrm{SO}_{4}$ terhadap pembuatan arang aktif batang tembakau sangat berpengaruh dengan variabel seperti kadar air, kadar abu, kadar zat terbang, kadar karbon murni, dan daya serap iodium. Kondisi tersebut didukung oleh hasil uji ANOVA dan uji lanjut dengan metode Tukey bahwa pada variabel kadar air, kadar abu, kadar zat terbang, kadar karbon murni, dan daya serap iodium mempunyai nilai yang berbeda secara nyata di tiap perlakuannya. Perlakuan terbaik dalam pembuatan arang aktif dari batang daun tembakau adalah penambahan konsentrasi $\mathrm{H}_{2} \mathrm{SO}_{4}$ 10\% dengan nilai kadar atau kandungan air 0,040\%, kandungan abu 0,035\%, kandungan zat terbang $0,877 \%$, kadar atau kandungan karbon terikat 99,088\% dan daya serap iodium 994,05 $\mathrm{mg} / \mathrm{g}$.

\section{Daftar Pustaka}

Asrijal, A., Chadijah, S., \& Aisyah, A. (2014). Variasi konsentrasi aktivator asam sulfat (H2SO4) pada karbon aktif ampas tebu terhadap kapasitas adsorpsi logam timbal. AlKimia, 2(1), 33-44. https://doi.org/https://doi.org/10.24252/al-kimia.v2i1.1636

Badan Pusat Statistik Provinsi Jawa Timur. (2018). Luas Areal Tanaman Perkebunan Menurut Kabupaten/Kota dan Jenis Tanaman Provinsi Jawa Timur. Retrieved from https://jatim.bps.go.id/statictable/2017/06/19/569/luas-tanaman-perkebunan-menurutkabupaten-kota-dan-jenis-tanaman-di-provinsi-jawa-timur-ha-2016-.html

Badan Standarisasi Nasional (BSN). (1995). SNI 06-3730-1995: Arang Aktif Teknis. Retrieved from https://pesta.bsn.go.id/produk/detail/4132-sni06-3730-1995

Budiono, A., Suhartana, \& Gunawan. (2009). Pengaruh aktivasi arang tenpurung kelapa dengan asam sulfat dan asam fosfat untuk adsorpsi fenol (Thesis). Retrieved from http://eprints.undip.ac.id/2893/

Himawanto, D. A., \& Nadjib, M. (2013). Pengeringan tembakau dengan sistem hybrid. Jurnal Ilmiah Semesta Teknika, 16(1), 1-9. Retrieved from https://journal.umy.ac.id/index.php/st/article/view/426

Indiarji, S. B. (2010). Pengaruh konsentrasi larutan pemasak dan waktu pemasakan terhadap rendemen dan sifat fisik pulp limbah batang tanaman tembakau (Nicotiana tabacum, l) melalui proses soda mekanis (Thesis). Retrieved from http://etd.repository.ugm.ac.id/home/detail_pencarian/167008

Jankowska, H., Swiatkowski, A., \& Chorma, J. (1991). Active Carbon. United Stated: Ellis Horwood

Kartikawati, L. (2016). Metode kromatografis lapis tipis-densitomtri untuk penentuan kadar nikotin batang tembakau (Nicotiana tabaccum L.) (Thesis). Retrieved from https://repository.unej.ac.id/

Lempang, M. (2014). Pembuatan dan kegunaan arang aktif. Info Teknis Eboni, 11(2), 65-80. Retrieved from http://ejournal.forda-mof.org/ejournallitbang/index.php/buleboni/article/view/5041/4463

Malik, U. (2013). Alternatif pemanfaatan limbah industri pengolahan kayu sebagai arang aktif. Jurnal Aptek, 5(1), 63-70. https://doi.org/https://doi.org/10.30606/aptk.v5i1.74

Muktianto, R. T., \& Diartho, H. C. (2018). Komoditas tembakau besuki Na-oogst dalam 
pespektif pembangunan berkelanjutan di Kabupaten Jember. Cakra Tani: Journal of Sustainable Agriculture, 33(2), 115-125. https://doi.org/http://dx.doi.org/10.20961/carakatani.v33i2.20598

Novita, E., Andriyani, I., Romadona, Z., \& Pradana, H. A. (2020). Pengaruh variasi jenis dan ukuran limbah organik terhadap kadar air kompos blok dan pertumbuhan tanaman cabai. Jurnal Presipitasi: Media Komunikasi Dan Pegembangan Teknik Lingkungan, 17(1), 19-28.

Perry, G. (2008). Perry's Chemical Engineering Handbook. McGrowHill Companies, Inc.

Sandi, A. P., \& Astuti. (2014). Pengaruh waktu aktivasi menggunakan h3po4 terhadap struktur dan ukuran pori karbon berbasis arang tempurung kemiri (Aleurites moluccana). Jurnal Fisika Unand, 3(2), 115-120. Retrieved from http://jfu.fmipa.unand.ac.id/index.php/jfu/article/view/96/78

Setiawati, E., \& Suroto, S. (2010). Pengaruh bahan aktivator pada pembuatan karbon aktif tempurung kelapa. Jurnal Riset Industri Hasil Hutan, 2(1), 21-28.

Sumarta, R. S. H., \& Sutapa, J. P. (2015). Pengaruh variasi jumlah perekat dan tekanan kempa terhadap sifat fisika-kimia briket arang dari limbah batang tanaman tembakau (Nicotiana tabacum L) (Thesis). Retrieved from https://repository.ugm.ac.id/

Ukanwa, K. S., Patchigolla, K., Anthony, E., \& Mandavgane, S. (2019). A review of chemicals to produce activated carbon from agricultural waste biomass. Sustainability (Switzerland), 11(6204), 1-35. https://doi.org/10.3390/su11226204 